FACTA UNIVERSITATIS

Series: Physical Education and Sport Vol. 16, N ${ }^{\mathrm{o}}$ 1, 2018, pp. 201 - 210

https://doi.org/10.22190/FUPES171015018M

Research article

\title{
THE IMPACT OF A 4-WEEK AEROBIC TRAINING PROGRAM ON THE AEROBIC STATUS OF TOP-LEVEL JUDOKAS
}

\author{
UDC 796.015.57
}

\section{Milenko Milošević, Predrag Nemec, Vesna Nemec, Miloš Milošević}

Faculty of Physical Education and Sports Management, University Singidunum,

Belgrade, Serbia

\begin{abstract}
The aim of this paper is to use a training methodology that we believe to be a powerful incentive for cardiovascular and metabolic adaptation via individually programmed aerobic running directly through the consumption of oxygen. The experiment was carried out on a top judo team of 9 competitors in a 4-week training period. The distribution of training loads ranged between the anaerobic threshold and maximum oxygen consumption. In four weeks of training, the judokas significantly improved their results for maximum oxygen consumption ( $\mathrm{VO}_{2}$ max) from $2 \%$ to $15 \%$, maximum relative oxygen consumption ( $\mathrm{VO}_{2}$ rel) from $2 \%$ to $16 \%$, the Cooper test $(\mathrm{K})$ from $2 \%$ to $15 \%$ and the speed at which the maximum amount of oxygen $\left(\mathrm{vVO}_{2}\right.$ max $)$ is expended, from $2 \%$ to $15 \%$. The judokas started from $64 \%$ to $83 \%$ of their genetic capacity in maximal oxygen consumption ( $\mathrm{VO}_{2} \mathrm{max}$ ), from $64 \%$ to $83 \%$ in maximum relative oxygen consumption $\left(\mathrm{VO}_{2} \mathrm{rel}\right)$ and $70 \%$ to $85 \%$ of the capacity at which they consumed the maximum amount of oxygen $\left(\mathrm{vVO}_{2} \mathrm{max}\right)$. After 4 weeks of training, $72 \%$ to $91 \%$ of the genetic capacity of maximum oxygen consumption ( $\mathrm{VO}_{2} \mathrm{max}$ ) ranged from $74 \%$ to $92 \%$ of the maximum relative oxygen consumption $\left(\mathrm{VO}_{2} \mathrm{rel}\right)$ and from $78 \%$ to $93 \%$ of the genetically projected capacity at the maximum amount of oxygen rate $\left(v V \mathrm{O}_{2} \max \right)$. In order to achieve these results, the judokas had to expend 943.80 to 1887.71 liters of oxygen $\left(\sum \mathrm{VO}_{2}\right)$ to cross a distance $\left(\sum \mathrm{DT}\right)$ from $67523.0 \mathrm{~m}$ to $102386.0 \mathrm{~m}$ and consume from 4719 to 9438.55 kilocalories ( $\left.\sum \mathrm{kcal}\right)$.
\end{abstract}

Key words: aerobic training, genetic capacities, energy, judo

Received October 15, 2017 / Accepted May 07, 2018

Corresponding author: Milenko Milošević

Faculty of Physical Education and Sports Management, University Singidunum, St. Danijelova 32 11000 Belgrade, Serbia

Phone: +381 113093 240• E-mail: mlsvc2010@ gmail.com 


\section{INTRODUCTION}

Two training models, continuous and discontinuous (intervals), were used for programming aerobic running. For the continuous training model, it is important to improve the capillary and oxidative muscle capacity while the interval training model improves the ability of the heart muscle to determine the key determinant of maximum oxygen consumption. In fact, intermediate methods are preferred. The Hoff-Helgerud method (Helgerud, Engen, Wisloff, Hoff, 2001) and the Billat method (Billat, 2001) are the most common methods. In the HoffHelgerud method, running control is performed via the heart rate and ranges between $90 \%$ and $95 \%$ of the maximum value. The Bilatt method is slightly different and uses speed $\left(\mathrm{vVO}_{2} \mathrm{max}\right)$ to achieve a maximum oxygen uptake $\left(\mathrm{VO}_{2} \mathrm{max}\right)$. The output sizes in both types of training are the distances run. In both cases it is possible to individualize training. In the first case, control is realized through the pulse and the second through running speed. Milošević et al. (Milošević, Nemec, Nemec, Milošević, 2017) in their continuous work achieved cardiovascular and metabolic adaptation, as in the interval training method, through individual aerobic running. They programmed the intensity of work for each participant so that it was found between the anaerobic threshold and the maximum oxygen consumption (Astrand, Rodahl, Dahl, Strømme, 2003, Kenney, Wilmore, Kostill, 2015, Klisuras, 2013, Wilmore \& Costil 2008, Milošević, et al., 2017). Their method implies that the individualization of aerobic training is programmed directly on the basis of the quantity of expended oxygen (Milosevic \& Milosevic, 2010, 2013 a, b, Milošević, et al., 2017). The programming, analysis and control of training in this paper was done based on the maximum and relative consumption of oxygen, the speed at which the maximum amount of oxygen was spent, the distances and energy consumed, the anaerobic threshold, the capacity values of oxygen consumption and the speed at which it was consumed (Milošević \& Milošević, Nemec, Jourkesh, Nemec, Milošević, David, 2016; Bouchard, Sarzynski, Rice, Kraus, Church, Sung, Rao, Rankin, 2011; Tucker \& Collins, 2012). For this purpose, the hardware software system (VAC Bioengineering, Belgrade) was used. It was programmed and controlled for training, in addition to an analysis of the results of a top judo team achieved over 4 weeks. Therefore, it can be said that the aim of this paper is to use a training methodology that we believe to be a powerful incentive for cardiovascular and metabolic adaptation by individually programmed aerobic running directly through the consumption of oxygen. By individualizing training, we avoided using the average values obtained in practice and scientific research work as reference values for programming the training of top athletes.

\section{MATERIALS AND METHODS}

\section{Participants}

The experimental data used for aerobic programming was obtained for the top judo team consisting of 9 competitors, average age $(\mathrm{AGE}=24.6$ years $)$, height $(\mathrm{BH}=178 \mathrm{~cm})$ and average weight $(\mathrm{BW}=82.6 \mathrm{~kg})$, winners of world and European medals. The sample of participants involved representatives of Serbia, all in full training. The participants gave their informed consent for the study procedures. The conditions of the study were approved by the University's ethics committee. 


\section{Programming methodology and control of aerobic running}

For programming and control of the training for development (aerobic potential) we used the training technology supported by a specially designed hardware and software system (VAC Bioengineering, Belgrade) (Tables 1 and 2). The programming of the training effect was based on quantified training goals, potential, training effects, changes and training work, in accordance with the current state of each tested judoka on a monthly basis (Milošević \& Milošević, 2010, 2013a, b). The training was conducted during 4 weeks - on Mondays, Tuesdays, Wednesdays, Fridays and Saturday mornings. Thursdays and Sundays were planned as breaks. Running in one training session took 20 minutes, and the training was programmed for 4 weeks or a month.

Table 1 Aerobic training - Week 1

\begin{tabular}{lccccc}
\hline+ Day & $\begin{array}{c}\text { Date } \\
(\text { mmddyy })\end{array}$ & $\begin{array}{c}\text { Distance } \\
(\mathrm{m})\end{array}$ & $\begin{array}{c}\text { Time } \\
(\mathrm{min})\end{array}$ & $\begin{array}{c}\text { Oxygen } \\
(\text { liter })\end{array}$ & $\begin{array}{c}\text { Energy } \\
(\mathrm{kcal})\end{array}$ \\
\hline Monday & 01.08 .16 & 4641 & 20 & 97.92 & 489.60 \\
Tuesday & 02.08 .16 & 3822 & 20 & 80.64 & 403.20 \\
Wednesday & 03.08 .16 & 4368 & 20 & 92.16 & 460.80 \\
Thursday & 04.08 .16 & PAUSE & & & \\
Friday & 05.08 .16 & 4586 & 20 & 96.77 & 483.85 \\
Saturday & 06.08 .16 & 4096 & 20 & 86.40 & 432.00 \\
Sunday & 07.08 .16 & PAUSE & & & \\
\hline Suma & \multicolumn{7}{c}{21513} & 100 & 453.89 & 2269.45 \\
\hline
\end{tabular}

Table 2 Aerobic training - Week 4

\begin{tabular}{lccccc}
\hline+ Day & $\begin{array}{c}\text { Date } \\
(\text { mmddyy })\end{array}$ & $\begin{array}{c}\text { Distance } \\
(\mathrm{m})\end{array}$ & $\begin{array}{c}\text { Time } \\
(\mathrm{min})\end{array}$ & $\begin{array}{c}\text { Oxygen } \\
(\text { liter })\end{array}$ & $\begin{array}{c}\text { Energy } \\
(\mathrm{kcal})\end{array}$ \\
\hline Monday & 22.08 .16 & 4368 & 20 & 92.16 & 460.80 \\
Tuesday & 23.08 .16 & 4095 & 20 & 86.40 & 432.00 \\
Wednesday & 24.08 .16 & 5460 & 20 & 115.20 & 576.00 \\
Thursday & 25.08 .16 & PAUSE & & & \\
Friday & 26.08 .16 & 4095 & 20 & 86.40 & 432.00 \\
Saturday & 27.08 .16 & 4368 & 20 & 91.16 & 455.80 \\
Sunday & 28.08 .16 & PAUSE & & & \\
\hline Suma & \multicolumn{7}{c}{22386} & 100 & 471.32 & 2356.60 \\
\hline
\end{tabular}

For the purposes of programming and controlling training effects and changes, age was used as well as body height, body weight and the Cooper 12-minute running test. Various aerobic parameters were calculated from these data (Milošević \& Milošević, 2010, 2013 a, b; Milošević, et al., 2017). The maximum relative consumption of oxygen was calculated according to the following equation:

$$
\text { VO2rel }=3.134304 .10-7 . \mathrm{K} 2+0.02077344 . \mathrm{K}-9.03125
$$

whereupon VO2rel is the maximum relative consumption of oxygen expressed in milliliters per kilogram of body weight in 1 minute $(\mathrm{ml} . \mathrm{kg}-1 . \mathrm{min}-1)$ and $\mathrm{K}$ is the value of the Cooper 12-minute running test in meters $(\mathrm{m})$. The maximum consumption of oxygen was calculated according to the following equation: 


$$
\mathrm{VO} 2 \max =[(3.134304 .10-7 . \mathrm{K} 2+0.02077344 . \mathrm{K}-9.03125) . \mathrm{BW}] .1000-1
$$

whereupon $\mathrm{VO}_{2}$ max is the maximum consumption of oxygen in liters per 1 minute $\left(\mathrm{L} \cdot \mathrm{min}^{-1}\right)$, $\mathrm{K}$ is the value of Cooper's 12-minute running test in meters $(\mathrm{m})$ and BW - body weight expressed in kilograms $(\mathrm{kg})$. The running speed at maximum oxygen consumption was calculated according to the following equation:

$$
\mathrm{vVO} 2 \mathrm{max}=0.0014 . \mathrm{K}+0.1786
$$

whereupon $\mathrm{VVO}_{2}$ max is the speed of running at $\mathrm{VO}_{2}$ max expressed in meters per second $\left(\mathrm{ms}^{-1}\right)$, and $\mathrm{K}$ is the value of Cooper's 12-minute running test in meters $(\mathrm{m})$. The value of the genetic capacity of the relative consumption of oxygen was calculated according to the following equation:

$$
\begin{aligned}
\mathrm{VO} 2 \mathrm{rel}(\mathrm{GK})=\mathrm{VO} 2 \mathrm{rel}(\mathrm{I})+ & 105 . \mathrm{e}[(-.02803419-.00040123 . \text { AGE }) . \text { VO2rel }(\mathrm{I})+ \\
& 0.0000003134304 . \text { AGE }]
\end{aligned}
$$

whereupon $\mathrm{VO}_{2} \mathrm{rel}(\mathrm{GK})$ is the genetic value of the maximum relative consumption of oxygen in milliliters per kilogram of weight per minute $\left(\mathrm{ml} . \mathrm{kg}^{-1} \cdot \mathrm{min}^{-1}\right), \mathrm{VO}_{2} \mathrm{rel}_{(\mathrm{I})}$ is the initial value of the maximum relative consumption of oxygen in milliliters per kilogram of body weight per minute $\left(\mathrm{ml} . \mathrm{kg}^{-1} \cdot \mathrm{min}^{-1}\right)$, AGE. The value of the genetic capacity of the maximum consumption of oxygen was calculated according to the following equation:

$$
\begin{aligned}
& \text { VO2max }(\mathrm{GK})=\{\text { VO2rel }(\mathrm{I})+105 . \mathrm{e}[(-.02803419-.00040123 . \text { AGE }) . \text { VO2rel (I) })+ \\
& \text { 0.0000003134304. AGE] . BW\} .1000-1 }
\end{aligned}
$$

whereupon $\mathrm{VO}_{2} \max (\mathrm{GK})$ is the maximum consumption of oxygen in liters per minute $\left(\mathrm{L} . \mathrm{min}^{-1}\right), \mathrm{VO}_{2} \mathrm{rel}(\mathrm{I})$ - initial value of maximum relative consumption of oxygen in milliliters per body weight per 1 minute $\left(\mathrm{ml} . \mathrm{kg}^{-1} \cdot \mathrm{min}^{-1}\right), \mathrm{AGE}$ and $\mathrm{BW}$ is the body weight in kilograms $(\mathrm{kg})$.

The lower limit of loading was at the anaerobic threshold. It, among other things, served to determine the range of distributing the monthly load of the participants (Klisuras 2013). The upper load limit for each participant was always measured by the maximum consumption of oxygen and the speed at which it was consumed. This type of load relates to judo as it belongs to anaerobic aerobic sports (Astrand, et al., 2003; Kenney, et al., 2015; Klisuras 2013; Wilmore \& Costil 2008).

Thus, the amount of oxygen that the judoka spends during a month of training (one of the training goals) is determined in conjunction with the training effects, changes and capacities of the equation (Milošević \& Milošević 2010, 2013 a, b; Milošević, et al., 2017):

$$
\text { VO2 }=1176.683+78.885 \text { (Month) }+2.277 \text { (Month)2 }
$$

whereupon $\mathrm{VO}_{2}$ is the total amount of consumed oxygen in liters per minute ( $\mathrm{L}$. $\mathrm{min}^{-1}$ ), Month - number of months in training.

When determining the amount of oxygen that will be spent in a month and in accordance with the other set goals, the expected effects and changes, the amount of oxygen for each training week is distributed (Table 1 and 2). Every week during a month there is one peak (95\% $\left.\mathrm{VO}_{2} \max \right)$, in the following week two peaks $\left(96 \% \mathrm{VO}_{2} \mathrm{max}\right)$, in the third week three peaks $(98 \%$ $\left.\mathrm{VO}_{2} \max \right)$ and in the fourth week again one peak $\left(100 \% \mathrm{VO}_{2} \mathrm{max}\right)$ (Milošević \& Milošević, 
2010, 2013 a, b; Milošević, et al., 2017). Oxygen consumption in other days ranges from 71\% to $92 \% \mathrm{VO}_{2} \max$ every week (Milošević \& Milošević, 2010, 2013, a, b; Milošević, et al., 2017). Each training session took 20 minutes. When determining the consumption of oxygen for every day of the week, especially for each judoka, the speed at which each training session was run (Table 1 and 2) was determined. The speed should allow the consumption of oxygen for a particular training day (Milošević \& Milošević, 2010, 2013, a, b; Milošević, et al., 2017). Multiplying the speed by 20 minutes gives the running distance for each training session and multiplying the consumption of oxygen by five gives the energy consumption (Table 1 and 2). After a month, the programmed training no longer gives the planned effects and the procedure of testing and programming of the training is repeated (Milošević \& Milošević, 2010, 2013 a, b, Milošević, et al., 2012, 2017).

\section{Data analysis}

The impact of the application of an educational training program on the development of aerobic potentials in top-level judokas was evaluated by primary data processing. Further, the comparison of the effects of the training changes obtained by consecutive successive measurements at different points in time under the influence of continuous aerobic training work was carried out by analyzing the variances. All measurement results were analyzed using the software package SPSS version 22.0

\section{RESULTS}

Table 3 presents the descriptive genetic capacity indicators and training description variables (Table 3). The fourth and fifth tables (Tables 4, 5) present the variable 12-minute Cooper running test $\left(\mathrm{K}_{(\mathrm{I})}\right.$ and $\left.\mathrm{K}_{(\mathrm{F})}\right)$, the running speed at which the maximum amount of oxygen is consumed $\left(\mathrm{vVO}_{2} \max _{(\mathrm{I})}\right.$ and $\left.\mathrm{vVO}_{2} \max _{(\mathrm{F})}\right)$, maximum oxygen consumption $\left(\mathrm{VO}_{2} \max _{(\mathrm{I})}\right.$ and $\left.\mathrm{VO}_{2} \max _{(\mathrm{F})}\right)$ and the maximum relative oxygen consumption $\left(\mathrm{VO}_{2} \mathrm{rel}_{(\mathrm{I})}\right.$ and $\left.\mathrm{VO}_{2} \mathrm{rel}_{(\mathrm{F})}\right)$. Table 6 analyzes the variance.

Table 3 Descriptive statistics of the genetic capacity variable and the training variable description

\begin{tabular}{llrrrrrrrr}
\hline & N & \multicolumn{1}{c}{ Range } & \multicolumn{1}{c}{ Min } & \multicolumn{1}{c}{ Max } & \multicolumn{1}{c}{ Mean } & Std. Dev. & Variance & Skew & Kurt \\
\hline VO2max & 9 & 2.09 & 4.43 & 6.52 & 5.27 & .76 & .59 & .78 & -.47 \\
VO2rel & 9 & 8.07 & 62.84 & 70.91 & 66.05 & 2.52 & 6.34 & .67 & .33 \\
vVO2max & 9 & .53 & 4.83 & 5.36 & 5.03 & .17 & .03 & .76 & .56 \\
$\sum \mathrm{DT}$ & 9 & 34863.00 & 67523.00 & 102386.00 & 80589.33 & 10106.84 & 102148127.00 & 1.17 & 2.20 \\
$\sum \mathrm{VO}_{2}$ & 9 & 943.91 & 943.80 & 1887.71 & 1404.56 & 290.23 & 84234.57 & .27 & -.02 \\
$\sum \mathrm{kcal}$ & 9 & 4719.55 & 4719.00 & 9438.55 & 7022.82 & 1451.16 & 2105864.16 & .27 & -.02 \\
\hline
\end{tabular}

Note: $\mathrm{VO}_{2} \max _{(\mathrm{GK})}-$ maximum rate of oxygen consumption measured during incremental exercise in liters per minute $\left(\mathrm{L} . \mathrm{min}^{-1}\right), \mathrm{VO}_{2} \mathrm{rel}_{(\mathrm{GK})}$ - the value of the genetic capacity of the maximum relative oxygen uptake in milliliters per

kilogram of body weight per minute $\left(\mathrm{ml}^{\mathrm{kg}}{ }^{-1} \cdot \mathrm{min}^{-1}\right), \mathrm{vVO}_{2} \max (\mathrm{GK})$ - the maximum oxygen uptake in meters $(\mathrm{m}), \sum$ DT - the total distance travelled in 4 weeks in meters $(\mathrm{m}), \sum \mathrm{VO}_{2}$ - total consumed $\mathrm{VO}_{2}$ in running during 4 weeks in liters per minute $\left(\mathrm{L} . \mathrm{min}^{-1}\right), \sum \mathrm{kcal}$ - the total consumed energy during 4 weeks of training 
Table 4 Descriptive statistics of the first measurement aerobic status variable

\begin{tabular}{ccrrrrrrrr}
\hline & $\mathrm{N}$ & \multicolumn{1}{c}{ Range } & \multicolumn{1}{c}{ Min } & \multicolumn{1}{c}{ Max } & \multicolumn{1}{c}{ Mean } & Std. Dev. & Variance & Skew & Kurt \\
\hline $\mathrm{K}_{(\mathrm{I})}$ & 9 & 820.00 & 2300.00 & 3120.00 & 2721.11 & 260.84 & 68036.11 & -0.09 & -0.58 \\
$\operatorname{vVO} \max _{(\mathrm{I})}$ & 9 & 1.15 & 3.40 & 4.55 & 3.99 & 0.37 & 0.13 & -0.10 & -0.55 \\
$\mathrm{VO} \max _{(\mathrm{I})}$ & 9 & 2.91 & 2.85 & 5.76 & 4.25 & 0.89 & 0.79 & 0.33 & 0.04 \\
$\mathrm{VO} \mathrm{rel}_{(\mathrm{I})}$ & 9 & 17.80 & 40.71 & 58.51 & 49.85 & 5.66 & 32.05 & -0.09 & -0.57 \\
\hline
\end{tabular}

Note: $\mathrm{K}_{(\mathrm{I}) \text { - }}$ initial values in Cooper's 12 -minute run test, $\mathrm{VO}_{2} \mathrm{max}_{(\mathrm{I})}$ - initial value of maximum rate of oxygen consumption, $\mathrm{VO}_{2} \mathrm{rel}_{(\mathrm{I})}$-. initial and transitive value of the maximum relative oxygen consumption.

Table 5 Descriptive statistics of the second measurement aerobic status variable

\begin{tabular}{|c|c|c|c|c|c|c|c|c|c|}
\hline & $\mathrm{N}$ & Range & Min & Max & Mean & Std. Dev. & Variance & Skew & Kurt \\
\hline $\mathrm{K}_{(\mathrm{I})}$ & 9 & 900.00 & 2600.00 & 3500.00 & 3023.3333 & 284.21 & 80775.00 & 0.14 & -0.36 \\
\hline $\mathrm{vVO} 2 \max _{(\mathrm{I})}$ & 9 & 0.99 & 3.82 & 4.81 & 4.3644 & 0.29 & 0.082 & -0.50 & 0.73 \\
\hline $\mathrm{VO} 2 \max _{(\mathrm{I})}$ & 9 & 2.68 & 3.21 & 5.89 & 4.5822 & 0.86 & 0.74 & 0.01 & -0.80 \\
\hline $\mathrm{VO}_{2} \mathrm{rel}_{(\mathrm{I})}$ & 9 & 15.41 & 47.22 & 62.63 & 55.4489 & 4.68 & 21.86 & -0.40 & -0.01 \\
\hline
\end{tabular}

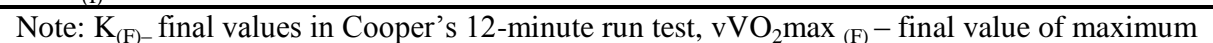
uptake of $\mathrm{VO}_{2} \max , \mathrm{VO}_{2} \max (\mathrm{F})$ - final values of maximum oxygen consumption, $\mathrm{VO}_{2} \mathrm{rel}_{(\mathrm{F})}$ - final values of maximum relative oxygen consumption.

Table 6 Variance analysis

\begin{tabular}{|c|c|c|c|c|c|c|}
\hline & & Sum of Squares & $\mathrm{df}$ & Mean Square & $\mathrm{F}$ & Sig. \\
\hline & Between Groups & 411022.22 & 1 & 411022.22 & & \\
\hline & Within Groups & 1190488.89 & 16 & 74405.56 & 5.52 & 0.03 \\
\hline & Total & 1601511.11 & 17 & & & \\
\hline \multirow{3}{*}{ vVO2max } & Between Groups & 0.63 & 1 & 0.63 & & \\
\hline & Within Groups & 1.72 & 16 & 0.11 & 5.82 & 0.03 \\
\hline & Total & 2.35 & 17 & & & \\
\hline \multirow{3}{*}{ VO2max } & Between Groups & 0.50 & 1 & 0.50 & & \\
\hline & Within Groups & 12.21 & 16 & 0.76 & 5.66 & 0.04 \\
\hline & Total & 12.71 & 17 & & & \\
\hline \multirow{3}{*}{ VO2rel } & Between Groups & 141.01 & 1 & 141.01 & & \\
\hline & Within Groups & 431.283 & 16 & 26.955 & 5.23 & 0.04 \\
\hline & Total & 572.291 & 17 & & & \\
\hline
\end{tabular}

Note: $\mathrm{K}_{-}$values of Cooper's 12-minute run test, $\mathrm{vVO}_{2} \max$ - value of running speed at $\mathrm{VO}_{2} \mathrm{max}$,

$\mathrm{VO}_{2}$ max-value $\mathrm{f}$ maximum oxygen consumption, $\mathrm{VO}_{2} \mathrm{rel}$ - values of maximum relative oxygen consumption

For all variables during the first and second measurement, errors in the estimates of average values in the population are very low and range from $1 \%$ to $6 \%$ for the entire sample (Table 3, 4, 5). Skewness and kurtosis for all the variables do not show significant deviations from the normal distribution (Table 3, 4, 5).

The results of the variance analysis (Table 6) confirm the existence of statistically significant differences in the five-percent risk level in all variables describing the aerobic status of the judokas, except in the variable maximum oxygen demand. 


\section{DISCUSSION}

The results (Tables $3,4,5,6$ ) show that in 4 weeks the judokas had significantly $(\mathrm{p}<.032 ; \mathrm{p}<.028 ; \mathrm{p}<.042 ; \mathrm{p}<.036)$ advanced in the maximum consumption of oxygen $\left(\mathrm{VO}_{2} \max \right)$ from $2 \%$ to $15 \%$, the maximum relative oxygen consumption $\left(\mathrm{VO}_{2} \mathrm{rel}\right)$ from $2 \%$ to $16 \%$, the Cooper test $(\mathrm{K})$ from $2 \%$ to $15 \%$ and the rate at which the maximum amount of oxygen was consumed (vVO2max) from $2 \%$ to $15 \%$ (Milošević \& Milošević, 2010, 2013, a, b; Milošević, et al., 2017). Those judokas who moved from lower values advanced even more. When they started training (Tables 3 and 4), they were at $64 \%$ to $83 \%$ of their genetic capacity at the maximum oxygen consumption $\left(\mathrm{VO}_{2} \mathrm{max}\right), 64 \%$ to $83 \%$ at the maximum relative oxygen consumption $\left(\mathrm{VO}_{2} \mathrm{rel}\right)$ and $70 \%$ to $85 \%$ at the speed at which they consume the maximum amount of oxygen $\left(\mathrm{vVO}_{2} \mathrm{max}\right)$. In order to achieve these results (Table 3), the judokas had to spend, during 4 weeks of training (20 trainings), from 943.80 to 1887.71 liters of oxygen $\left(\left(\sum \mathrm{VO}_{2}\right)\right.$ to cross a distance $\left(\sum \mathrm{DT}\right)$ from $67523.0 \mathrm{~m}$ to $102386.0 \mathrm{~m}$ and consume 4719 to 9438.55 kilocalories ( $\sum \mathrm{kcal}$ ) (Helgerud, et al., 2001; Milošević \& Milošević, 2010, 2013, a, b; Milošević, et al., 2017). The lowest aerobic running energy at 4 weeks was 2.85 liters per minute (L min-1) and 14.25 kilocalories (kcal), and the highest aerobic energy was 5.76 liters per minute (L min-1) and 28.8 kilocalories (kcal).

The judokas were programmed (Table 3 ) in such a way that their minimum value is the maximum oxygen consumption $\left(\mathrm{VO}_{2} \mathrm{max}(\mathrm{GK})\right.$ ) of 4.3 liters per minute ( $\mathrm{L}$ min-1), the average value is 5.27 liters per minute ( $\mathrm{L}$ min-1), and the maximum value is 6.52 liters per minute ( $\mathrm{L}$ min-1). Further, a minimum value of the maximum relative oxygen consumption $\left(\mathrm{VO}_{2} \mathrm{rel}(\mathrm{GK})\right.$ of 62.84 milliliters per kilogram of weight per minute (ml.kg-1.min-1), the average value of 66.05 milliliters per kilogram of weight per minute (ml.kg-1.min-1) and a maximum value of 70.91 milliliter per kilogram of weight per minute (ml.kg-1.min-1), and finally a minimum value at the genetically projected rate $\left(\mathrm{vVO}_{2} \max (\mathrm{GK})\right.$ reaching 4.83 meters per second (ms-1), the average value at 5.03 meters per second (ms-1) and the maximum value at 5.36 meters per second (ms-1) (Milošević \& Milošević, 2010, 2013 a, b; Milošević, et al., 2012, 2016, 2017; Bouchard, et al., 2011; Tucker \& Collins, 2012).

After 4 weeks of training (Tables $3,5,6$ ), we equated the team with all the aerobic variables. Under the influence of the described program (Tables 3, 5, 6), the maximum oxygen consumption $\left(\mathrm{VO}_{2} \mathrm{max}\right)$ in the judokas improved and ranged from $72 \%$ to $91 \%$ of the genetic capacity. One competitor had a minimum value and one competitor had the maximum value of maximum oxygen consumption $\left(\mathrm{VO}_{2} \mathrm{max}\right)$ and other competitors had scores ranging between $84 \%$ and $86 \%$ of their genetic capacity. For the next month of this training, all judokas could attain $96 \%$ of the capacity values (Milošević \& Milošević, 2010, 2013, a, b; Milošević, et al., 2012, 2016, 2017; Bouchard, et al., 2011; Tucker \& Collins, 2012).

Within the program, the maximum relative oxygen consumption $\left(\mathrm{VO}_{2} \mathrm{rel}\right)$ significantly $(\mathrm{p}<.036)$ improved and ranged from $74 \%$ to $92 \%$ of the genetic capacity (Tables 3, 5, 6). The same competitor was low at the level of $74 \%$ and the rest were mostly around $87 \%$ of the capacity. And in the maximum relative consumption of oxygen $\left(\mathrm{VO}_{2} \mathrm{rel}\right)$, all the judokas could reach $96 \%$ of their genetic capacity under the influence of this type of exercise program (Milošević \& Milošević, 2010, 2013, 2014, a, b, Milošević, et al., 2012, 2016, 2017; Bouchard et al., 2011; Tucker \& Collins, 2012). 
Similarly, there was a velocity $\left(\mathrm{vVO}_{2} \max \right)$ at which the maximum amount of oxygen was consumed (Tables $3,5,6)$. The rate $\left(\mathrm{vVO}_{2} \max \right)$ significantly $(\mathrm{p}<.028)$ improved and ranged from $78 \%$ to $93 \%$ of the genetically projected capacity. And at the rate at which the maximum amount of oxygen was consumed $\left(\mathrm{vVO}_{2} \mathrm{max}\right)$, all judokas could reach $96 \%$ of their genetic capacity within this type of training program (Milošević \& Milošević, 2010, 2013, a, b; Milošević, et al., 2012, 2016, 2017; Bouchard, et al., 2011; Tucker \& Collins, 2012).

The load distribution (Table 3) in the applied training program during one week looks like this: $35 \%$ of the total training time is $95 \%, 100 \% \mathrm{VO}_{2} \max$, the intensity of $80 \%$ to $92 \%$ of was $35 \%$ and the intensity from 71 to $75 \%$, with $30 \%$ of the total training time (Milošević \& Milošević, 2010, 2013, 2014, a, b; Milošević, et al., 2017). Such a distributed workload in training is a powerful incentive to increase cardio-respiratory adaptation, the oxidative capacity of skeletal muscle, mitochondrial biogenesis and other physiological adaptations of judokas (Astrand, et al., 2003; Kenney, et al., 2015; Klisuras 2013; Wilmore \& Costil 2008). A four-time repetition of his type of loading contributes to the described response of the body and the produced effects (Milošević \& Milošević, 2010, 2013, 2014, a, b; Milošević, et al., 2017).

The paper used a methodology (Milošević \& Milošević, 2010, 2013, a, b; Milošević, et al., 2017), which allows an assessment of the dynamics of aerobic status development, the quantification of training goals and the individual's individualization based on an estimated capacity instead of its current state. The methodology also provides individual programming of training and control of training effects and changes using modern hardware and software (Milošević \& Milošević, 2010, 2013, a, b; Milošević, et al., 2016, 2017).

The suggested methodology can be used in any sport of an aerobic anaerobic character to create top athletes. It can be used in the population of pupils and students as well as in sports schools (Cvejić \& Ostojić, 2017). By simply applying the proposed methodology, aerobic genetic capacity (selection) can be estimated for each individual. Training programs can be programmed both for trainings and classes, in addition. Monitoring aerobic development as well as control of training and work in classes, is possible by using the set of proposed variables described in the paper.

\section{CONCLUSIONS}

The results in this paper show that it is possible to individualize and control aerobic training directly through the consumption of oxygen. For four weeks of training, the judokas significantly improved their result of a maximum oxygen consumption $\left(\mathrm{VO}_{2} \mathrm{max}\right)$ from $2 \%$ to $15 \%$, maximum relative oxygen consumption $\left(\mathrm{VO}_{2}\right.$ rel $)$ of $2 \%$ up to $16 \%$, the Cooper test (K) from $2 \%$ to $15 \%$ and the rate at which they consume the maximum amount of oxygen $\left(\mathrm{vVO}_{2} \max \right)$ from $2 \%$ to $15 \%$. The judokas started from $64 \%$ to $83 \%$ of their genetic capacity in a maximum oxygen consumption $\left(\mathrm{VO}_{2} \mathrm{max}\right)$, from $64 \%$ to $83 \%$ in the maximum relative oxygen consumption $\left(\mathrm{VO}_{2}\right.$ rel $)$ and $70 \%$ to $85 \%$ of the capacity at which they consumed the maximum amount of oxygen $\left(\mathrm{vVO}_{2} \mathrm{max}\right)$. After 4 weeks of training, $72 \%$ to $91 \%$ of the genetic capacity of maximum oxygen consumption $\left(\mathrm{VO}_{2} \max \right)$ ranged from $74 \%$ to $92 \%$ of the maximum relative oxygen consumption $\left(\mathrm{VO}_{2} \mathrm{rel}\right)$ and from $78 \%$ to $93 \%$ of the genetically designed capacity at the rate at which they consume 
the maximum amount of oxygen $\left(\mathrm{vVO}_{2} \mathrm{max}\right)$. To achieve these results, the judokas had to consume 943.80 to 1887.71 liters of oxygen $\left(\sum \mathrm{VO}_{2}\right)$ to cross the distance $(\Sigma \mathrm{DT})$ from $67523.0 \mathrm{~m}$ to $102386.0 \mathrm{~m}$ and consume energy from 4719 to 9438.55 kilocalories $(\Sigma \mathrm{kcal})$. The smallest aerobic power that runs in the 4-week range is 2.85 liters per minute (L min-1) and 14.25 kilocalories (kcal), and the highest aerobic power was 5.76 liters per minute (L min-1) and 28.8 kilocalories (kcal).

\section{REFERENCES}

Astrand, P. O., Rodahl, K., Dahl, H. A., Strømme, S. B. (2003). Textbook of work physiology. Physiological bases of exercise. Champaign, Ill.: Human Kinetics.

Billat, V. (2001). Interval training for performance: a scientific and empirical practice. Sports medicine, 31(1): 13-31.

Bouchard, C., Sarzynski, M. A., Rice, T. K., Kraus, W. E., Church, T. S., Sung, Y. J., Rao, D. C., Rankinen, I. (2011). Genomic predictors of the maximal $\mathrm{O}_{2}$ uptake response to standardized exercise training programs. Journal of Applied Physiology, 110(5):1160-70.

Cvejić, D., Ostojić, S. (2017). Effects of the fitt program on physical activity and health-related fitness in primary school age children. Facta universitatis - Series: Psysical education and sport, 15(3):437-451.

Helgerud, J., Engen, L. C., Wisloff, U., Hoff, J. (2001). Aerobic endurance training improves soccer performance. Medicine and science in sports and exercise, 33(11): 1925-1931.

Kenney, W. L., Wilmore, J. H., Kostill, D. L. (2015). Physiology of sport and exercise. Champaign IL: Human Kinetics.

Klisuras, V. (2013). Fundamentals of sports physiology. Belgrade, Serbia: Institute for Sports.

Milošević, B. M., Milošević, M. M. (2010). Physical preparation of elite athletes: standardization of management processes. Belgrade, Serbia: APP.

Milošević, M. M., Mudrić, M., Mudrić, R. \& Milošević, B. M. (2012). Using the mind in reprogramming the limits of muscle force in the process of creating champions. Sport science \& practice, 2(5) 39-58.

Milošević, B. M., Milošević, M. M. (2013a). Model for assessing the physical status, as well as prediction and programming of training and sports performance of a soccer player. Journal of Physical Education and Sport, 13(4) 479-488.

Milošević, B. M., Milošević, M. M. (2013b). Special Physical Education: scientific basis. Belgrade, Serbia: CEDIP.

Milošević, B. M., \& Milošević, M. M. (2014). SPECIAL PHYSICAL EDUCATION: Textbook on the management of the construction of the physical integrity and capacity of police officers. Saarbrücken, Germany: LAP Lambert Academic Publishing.

Milošević, B. M., Nemec, J. V., Jourkesh, M., Nemec, M. P., Milošević, M, M., David. G. B. (2016). Determination of capacity and rules of the variability of maximum force using nonlinear mathematical models: a case study. Central European Journal of Sport Sciences and Medicine. 16(4): 91-101.

Milošević, M. B., Nemec, V., Nemec, P., Milošević, M. M., (2017). Programming methodology and control of aerobic training by running, Acta Kinesiologica. 11(1) 53-57.

Tucker, R., Collins, M. (2012). What makes champions? A review of the relative contribution of genes and training to sporting success. British Journal of Sports Medicine, 46(8), 555-561.

Wilmore, J. H., Costill, D. L. (2008). Physiology of sport and exercise. Champaign, II: Human Kinetics. 


\section{UTICAJ ČETVORONEDELJNOG AEROBNOG TRENINGA NA AEROBNI STATUS VRHUNSKIH DŽUDISTA}

Cilj ovog rada je korišćenje trenažne metodologije za koju smatramo da je moćan podsticaj kardiovaskularne i metaboličke adaptacije, individualno programiranim aerobnim treningom trčanjem, direktno preko potrošnje kiseonika. Eksperiment je sproveden na vrhunskoj džudo ekipi 9 takmičara u vremenu od 4 nedelje treninga. Distribucija trenažnih opterećenja nalazila se u rasponu između anaerobnog praga i maksimalne potrošnje kiseonika. Za četiri nedelje treninga džudisti su značajno popravili rezultat u maksimalnoj potrošnji kiseonika (VO2max) od $2 \%$ do $15 \%$, maksimalnoj relativnoj potrošnji kiseonika (VO2rel) od 2\% do 16\%, Kuperovom testu (K) od 2\% do $15 \%$ i brzini na kojoj troši maksimalnu količinu kiseonika (vVO2max) od 2\% do 15\%. Džudisti su startovali od 64\% do $83 \%$ svog genetskog kapaciteta u maksimalnoj potrošnji kiseonika (VO2max), od 64\% do 83\% u maksimalnoj relativnoj potrošnji kiseonika (VO2rel) i 70\% do 85\% kapaciteta u brzini na kojoj troše maksimalnu količinu kiseonika (vVO2max). Posle 4 nedelje treninga došli su od $72 \%$ do 91\% genetskog kapaciteta maksimalne potrošnje kiseonika (VO2max), odnosno od 74\% do 92\% maksimalne relativne potrošnje kiseonika (VO2rel) $i$ od 78\% do 93\% genetski projektovanih kapaciteta u brzini na kojoj troše maksimalnu količinu kiseonika (vVO2max). Da bi postigli te rezultate džudisti su morali da potroše od

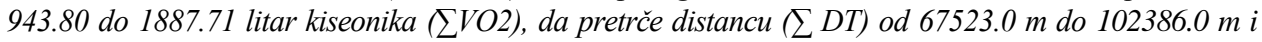
potroše energije od 4719 do 9438.55 kilokalorija ( $\sum$ kcal).

Ključne reči: aerobni trening, genetski kapaciteti, energija, judo 